\title{
THE IMMATURE STAGES OF Eurymerus eburioides AUDINET-SERVILLE, 1833 (COLEOPTERA: CERAMBYCIDAE: ECTENESSINI)
}

\author{
MORELLI, E., ${ }^{1}$ SANCHEZ, A. ${ }^{2}$ and BIANCHI, M. ${ }^{2}$ \\ ${ }^{1}$ Sección Entomología, Facultad de Ciencias, Iguá, 4225, Montevideo 11400, Uruguay \\ ${ }^{2}$ Protección Forestal, Facultad de Agronomía, Avda. Garzón, 780, Montevideo 12900, Uruguay \\ Correspondence to: Enrique Morelli, Sección Entomología, Facultad de Ciencias, Iguá, 4225, Montevideo 11400, \\ Uruguay, e-mail: emorelli@fcien.edu.uy \\ Received October 28, 2003 - Accepted July 16, 2004 - Distributed February 28, 2005 \\ (With 13 figures)
}

\begin{abstract}
Last instar larva and pupa of Eurymerus eburioides Audinet-Serville, 1833, are described and illustrated based on specimens reared from neonate larvae on Eucalyptus globulus globulus logs in the laboratory. Characters of possible diagnostic value are presented in this work.
\end{abstract}

Key words: Coleoptera, Cerambycidae, Eurymerus, larva, pupa.

\section{RESUMO}

\section{Estágios imaturos de Eurymerus eburioides Audinet-serville, 1833 (Coleoptera: Cerambycidae: Ectenessini)}

Neste trabalho são descritas a larva do último instar e a pupa de Eurymerus eburioides Audinet-Serville, 1833, com base em espécimes criados em laboratório a partir de larvas neonatas de Eucalyptus globulus globulus. Apresentam-se, também, características com possível valor diagnóstico.

Palavras-chave: Coleoptera, Cerambycidae, Eurymerus, larva, pupa.

\section{INTRODUCTION}

Eurymerus eburioides Audinet-Serville is a native cerambicid often found attacking Eucalipt in South America (Bosq, 1934; Costa, 1943; Hayward, 1960; Bienzanko \& Bosq, 1956; Berti Filho, 1985; Moraes \& Berti-Filho, 1974; Monné et al., 2002). Its distribution area spreads over Brasil (Goiás, Mato Grosso, and Pernambuco to Rio Grande do Sul), Paraguay, Uruguay, and Argentina (Monné, 1994). Main hosts of this insect are species of indigenous Myrtaceae (Ruffinelli \& Carbonell, 1954; Ruffinelli, 1967; Monné, 1970). It attacks stressed trees and newly felled timber. Larvae bore parallel galleries along the phloem of logs and thick branches. Fully developed larvae penetrate through the xylem to pupate.

This work contributes to the knowledge of the complex of borer larvae attacking Eucalyputs sp.

\section{MATERIAL AND METHODS}

E. eburioides beetles were reared in the laboratory on one of their hosts (Eucalyptus globulus globulus). Neonate larvae were manually transferred to logs kept in a controlled-environment chamber $\left(25 \pm 2^{\circ} \mathrm{C}\right.$; photoperiod, 12:12 h. L:D). To describe the mature larvae and pupae, they were removed from these logs and examined; larval and pupal characters were based on Duffy (1960), Costa et al. (1988), and Stehr (1991).

\section{RESULTS}

\section{Description of the last instar larva (Figs. 1-11)}

Mature larva (Fig. 1). Total length $22 \pm 4 \mathrm{~mm}$ $(\mathrm{n}=8)$. Form: robust and ventrally depressed, dorsal area rather convex. Tegument: milky-white. Pronotal chaetotaxy: light castaneous. Head prognated, retracted 
into prothorax (Figs. 23); maximum width of the head capsule: $4.10 \pm 0.50 \mathrm{~mm}(\mathrm{n}=8)$. Epicranial suture slightly visible. Clipeal borders cuneiform. Antennae very short, 3 -segmented. The first segment wider, 1.5 longer than the second; last segment shorter than the others with apical microsetae. Elongate dorsal setae present on the distal border, in the first and second segment. Labrum (Fig. 8) wider than long; lateral borders externally prolonged. Round distal margin, covered with long setae; lateral areas with scattered short setae defining a glabrous central area. Epipharynx (Fig. 9) with small spiniform setae present on distal area, and long and fine setae in lateral areas. Quadrangular symmetrical mandibles with broad base (Figs. 5-7). Blunt molar region. Two scissorial teeth separated with an important scissorial notch. Maxilla (Fig. 10). Cardo and stipe sub-equal, giving the maxilla a globular shape. Long setae arranged in a line at the base and on the distal border. Maxillary palpi with 3 articles, the last one small and round. Labium (Fig. 10). Quadrangular prementum and mentum. Mentum with elongate setae in the central region. Labial palpi with 2 segments and long setae in the intersegmental region. Supraocellar setose area with 8 setae, 3 at the base, 3 central arranged in a line, and 2 distal (Fig. 4). Pronotum twice broader than long, anterior margin short and sinuous, low margin with a central notch (Fig. 2). Dorsal-lateral suture towards upper margin. Upper $2 / 3$ with short and densely distributed setae, scattered setae on the lateral margin, the remainder basal 1/3 glabrous. Abdomen. X segment quadrangular, broader than long with 12-14 long setae in the median region (Fig. 11).

\section{Description of the pupa (Figs. 12, 13)}

Total length: $20 \mathrm{~mm} \pm 2 \mathrm{~mm}(\mathrm{n}=7)$ and $19 \pm$ $2 \mathrm{~mm}(\mathrm{n}=9)$, males and females respectively: maximum width of pronotum: $3.90 \pm 0.40 \mathrm{~mm}(\mathrm{n}=$ 7) and $3.40 \pm 0.30 \mathrm{~mm}(\mathrm{n}=9)$, males and females respectively. Adectic and exarate, milky white tegument. Globose pronotum, anterior margin small, lateral margins curved, ending in a little round lobe. Fine setae mainly on the median region. Abdomen elongate and narrow. Dorsa of segments with irregular rows of spiniform setae, more distinct on VIII segment.

\section{DISCUSSION}

Martins (1998) affirmed that Cerambycinae systematic at the tribe level is "chaotic" for South American genera and suggested new tribes and some modifications in the species they include. Based on this opinion, this author transferred E. eburioides, which until then belonged to Achrysonini tribe, to the tribe Ectenessini. This tribe includes Achryson surinamum, which is a cerambicid also present in Uruguay and has as host, among other trees species, Eucalyptus sp. (Monné, 1970).

The mature larva of Achryson surinamum described by Duffy (1960) presents some characters absent in E. eburioides mature larvae, like abdomen with dorsal ampullae and pleural disc granulate and distinct on abdominal segments 1-3; tergite IX with a pair of paramedian, oval, and testaceous carinae or tubercles, which are rather faint in some specimens.

Morelli et al. (in press) used supraocellar and tergite $\mathrm{X}$ chaetotaxy to complete the morphological identification of Phoracantha recurva Newman and Phoracantha semipunctata Fabricius. In the same way, the characters described for $E$. eburioides in this work, like number and distribution of the supraocellar setae ( 3 at the base, 3 central arranged in a line, and 2 distal) and $\mathrm{X}$ abdominal segment chaetotaxy (12-14 long setae in the median region), could be features to take into account in giving new foundations to the Ectenessini tribe.

Acknowledgements - This work was partially supported financially by the Instituto Nacional de Investigación Agropecuaria (INIA). We thank the agricultural engineer Rafael Escudero for his help in field work. 

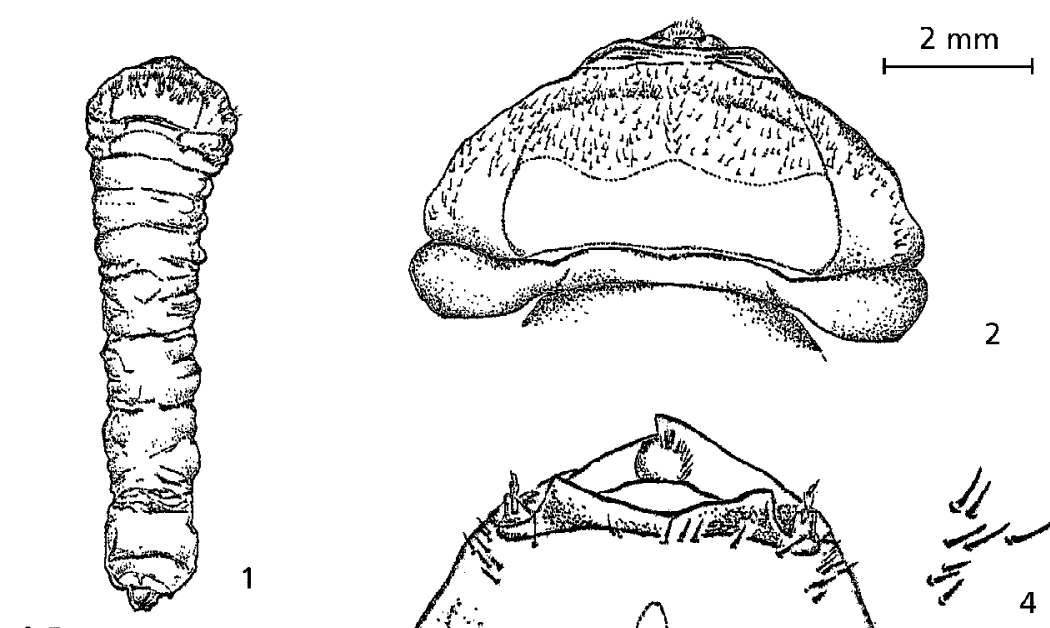

$0.5 \mathrm{~mm}$
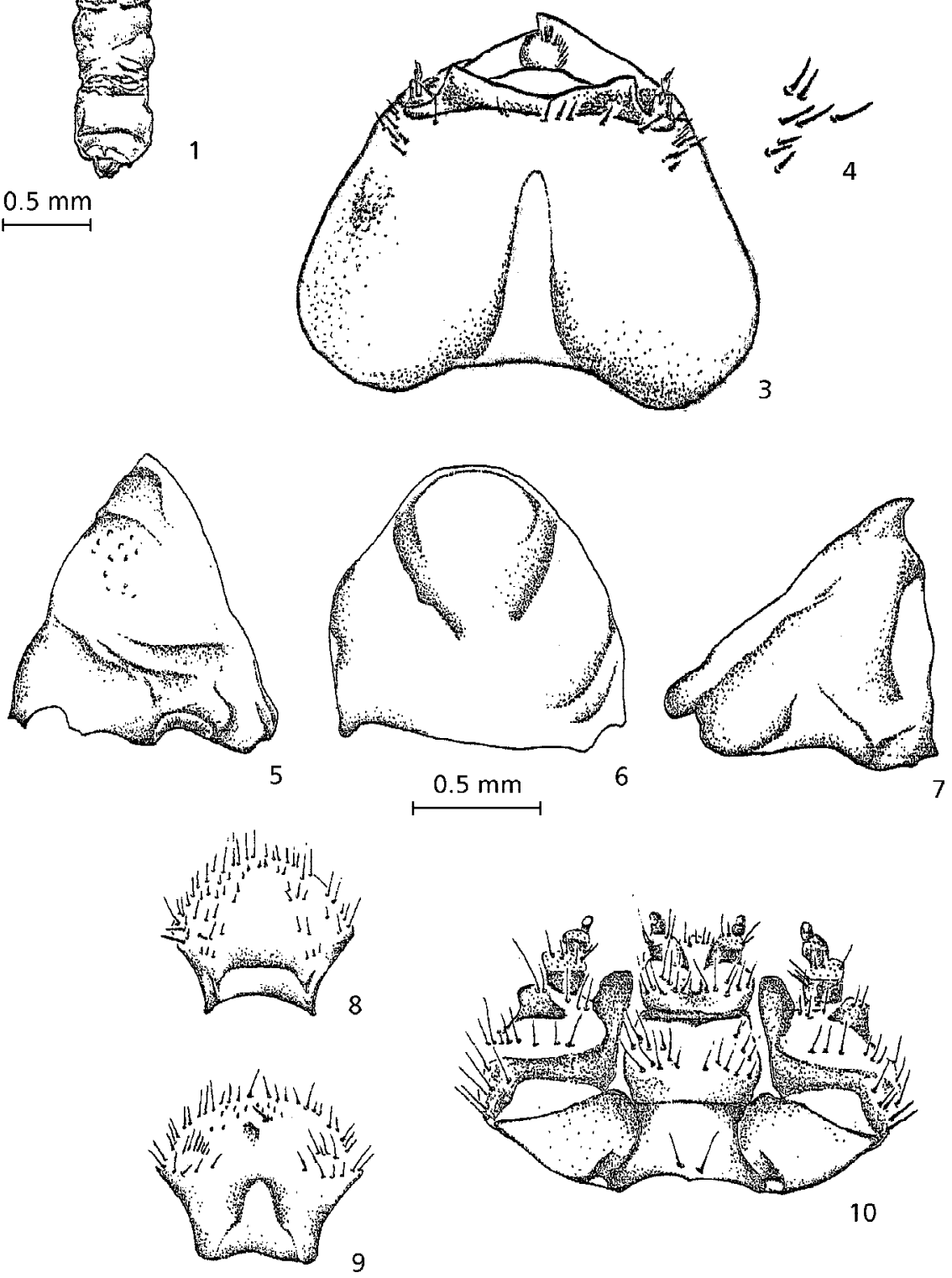

Figs. 1-10 - Eurymerus eburioides (Audinet-Serville). 1 - larva, dorsal view; $\mathbf{2}$ - head, $1^{\text {st }}$ and $2^{\text {nd }}$ thoracic segment, dorsal view; 3 - head, dorsal view; 4 - supraocellar chaeototaxy; $\mathbf{5}$ - right mandible dorsal view; 6 - right mandible inner surface; 7 - right mandible ventral view; 8 - labrum; 9 - epipharynx; 10 - maxilla and labium, ventral view. 


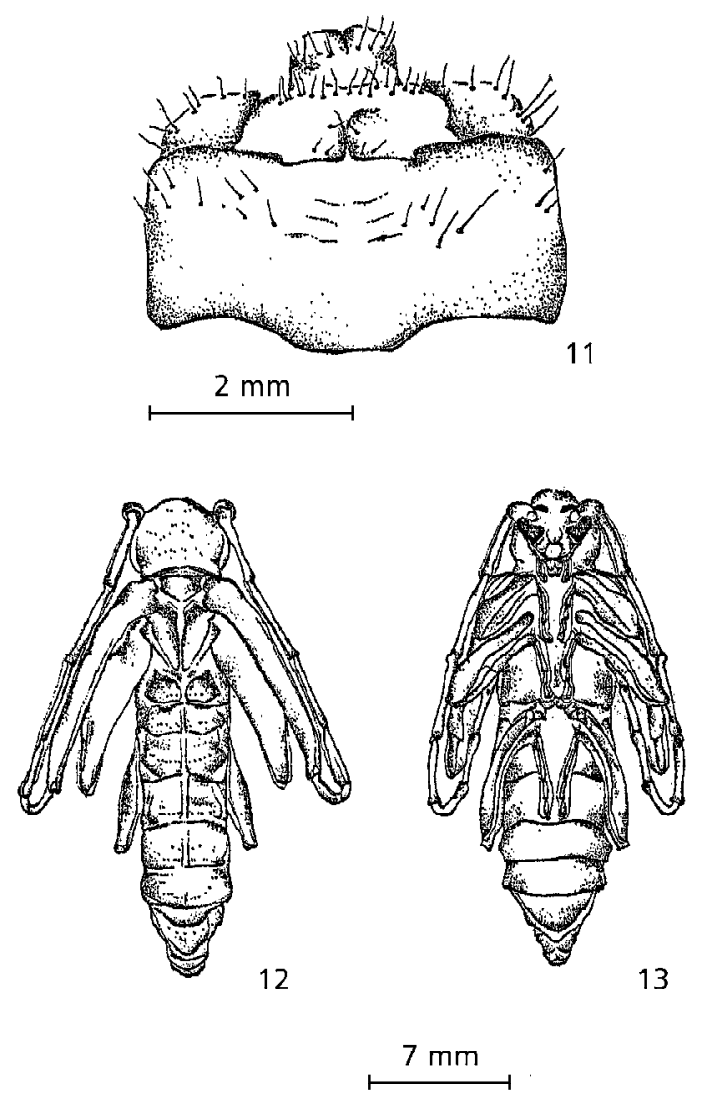

Figs. 11-13 - Eurymerus eburioides (Audinet-Serville). 11 - X-segment, ventral view; 12 - pupa, dorsal view; 13 - pupa, ventral view. Scale line in $\mathrm{mm}$.

\section{REFERENCES}

BERTI FILHO, E., 1985, Insects associated to eucalipt plantations in Brazil. pp. 162-178. In: IUFRO WP. S2.07.07. Protection of forest in the tropics. Noxious insects to pine and eucalypt plantations in the tropics. Universidade Federal do Paraná, Curitiba.

BIEZANKO, C. M. \& BOSQ, J. M., 1956, Cerambycidae de Pelotas e seus arredores. Agros, Pelotas, 10(3-4):3-15, 1 pl.

BOSQ, J. M., 1934. Primera lista de los coleópteros de la República Argentina dañinos a la Agricultura. Bol. Min. Agric., B. Aires, 36(4): 313-346.

COSTA, R. G., 1943, Pragas das plantas cultivadas do Rio Grande do Sul. Livr. Continente, P. Alegre, 75p., 147 figs.

COSTA, C., VANIN, S. A. \& CASARI-CHEN, S. A., 1988, Larvas de Coleoptera do Brasil. Museu de Zoologia, Universidade de São Paulo, FAPESP, 282p., 165 PL.

DUFFY, E., 1960, A monograph of the immature stages of neotropical timber beetles (Cerambycidae). British Museum, London, 327p.

HAYWARD, K. J., 1960, Insectos tucumanos perjudiciales. Revta. Ind. Agríc. Tucumán, 42(1): 3-144.

MARTINS, U. R., 1998, Cerambycidae sul-americanos (Coleoptera). Taxonomia. Sociedade Brasileira de Entomologia, 2: 104-114.
MONNÉ, M., 1970, Fauna de los coleópteros del Uruguay. Tesis Ing. Agr. Fac. de Agronomía, Montevideo, Uruguay, 216p.

MONNÉ, M., 1994, Catalogue of the Cerambycidae (Coloeptera) of the Western Hemisphere. Sociedade Brasileira de Entomologia, São Paulo, 22v.

MONNÉ, M., BIANCHI, M., SANCHEZ, A. \& ESCUDERO, R., 2002, Cerambícidos (Coleoptera) que atacan Eucalyptus globulus y Eucalyptus grandis en Uruguay. Agrociencia, VI(1): 63-68.

MORAES, G. J. \& BERTI- FILHO, E., 1974, Coleobrocas que ocorrem em essências florestais. IPEF 9, Piracicaba, SP.

MORELLI, E., BIANCHI, M. \& SANCHEZ, A. (in press). The immature stages of Phoracantha recurva Newman, 1842 and Phoracantha semipunctata Fabricius, 1775 (Coleoptera: Cerambycidae) and a key to larvae of these species. Brazilian Journal of Biology.

RUFFINELLI, A., 1967, Insectos y otros vertebrados de interés forestal. Silvicultura, Uruguay, 25: 3-79.

RUFFINELLI, A. \& CARBONELL, C., 1954, Segunda lista de insectos y otros artrópodos de importancia económica en el Uruguay. Universidad de la República, Facultad de Agronomía, Montevideo, 52p.

STEHR, F. W., 1991, Immature insects. Kendall/Hunt Publishing Company, USA, 2. vol., p. 975. 